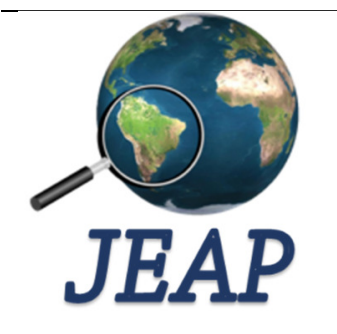

ISSN: 2525-815X

\section{Journal of Environmental} Analysis and Progress

\author{
Journal homepage: www.ufrpe.br/jeap
}

http://dx.doi.org/10.24221/jeap.2.1.2017.1005.16-22

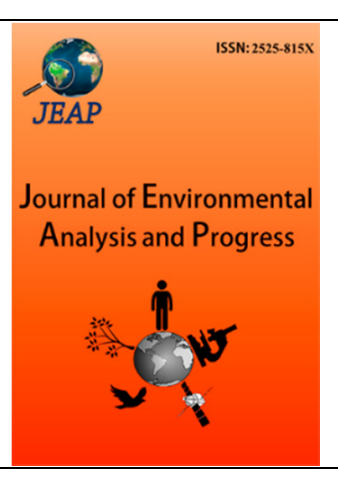

\title{
Infestation of Crassostrea cf. brasiliana by boring-polychaete polydorids in estuaries from Northeastern Brazil
}

\author{
José Roberto Botelho de Souza ${ }^{\mathrm{ab}}$, Paulo Henrique Oliveira Bonifácio ${ }^{\mathrm{b}}$, José Eriberto de Assis ${ }^{\mathrm{a}}$ \\ ${ }^{a}$ Laboratório de Comunidades Marinhas, Centro de Ciências Biológicas, Universidade Federal de Pernambuco-UFPE, \\ Av. Prof. Moraes Rego, S/N, Cidade Universitária, Recife-PE, Brasil. CEP: 50670-420. \\ ${ }^{\text {b }}$ Programa de Pós-Graduação em Biologia Animal-PPGBA, Departmento de Zoologia, CCB-UFPE, Av. Prof. Moraes \\ Rego, S/N, Cidade Universitária, Recife-PE, Brasil. CEP: 50670-420. E-mail: jrbsouzq@ gmail.com.
}

\begin{tabular}{|c|c|}
\hline A R T I C L E I N F O & A B S T R A C T \\
\hline Received 13 Oct 2016 & The presence of polydorids shell-borer and the epifaunal polychaetes on \\
\hline Accepted 26 Dec 2016 & Crassostrea cf. brasiliana were studied in five estuaries in Northeastern Brazil. The \\
\hline Published 31 Jan 2017 & $\begin{array}{l}\text { prevalence of shell-boring polychaetes in oysters varied significantly, showing the } \\
\text { dominance of Polydora websteri, with } 57 \% \text { of sampled oysters, and Boccardiella } \\
\text { ligerica, with } 11 \% \text {, but the prevalence was significantly different among estuaries } \\
\text { sampled. Capibaribe River showed the highest infestation, with } 81 \% \text { these mud- } \\
\text { blisters, but in Massangana River had no presence of these polychaetes. The linear } \\
\text { regression between the number of polychaetes and the size of oysters was } \\
\text { significant, suggesting that infestation increases with age. } \\
\text { Keywords: Polychaeta, benthos interspecific association, bivalvia. }\end{array}$ \\
\hline
\end{tabular}

\section{Introduction}

The family Spionidae has more than 500 nominal species, and 35 genera (Radashevsky, 2012), that live in a variety of marine environments from sandy beaches to limestone substrate (Williams, 2000). Among this family, only the polydorid species present a modification of chaetiger and have the ability to bore into calcareous substrata that seem to be widespread among the species of the genera Polydora and Dipolydora (Sato-Okoshi, 2000). However, some species of the following spionid genera infest calcareous substrates as mollusk shells: Amphipolydora, Boccardia, Boccardiella, Carazziella, Dipolydora, Polydora, Pseudopolydora and Tripolydora (Bower et al., 1994; Blake, 1996). Species from the genus Polydora make holes in a substrate containing calcium carbonates as rock or coralline algae, like oysters, mussels, and gastropods (Boscolo \& Giovanardi, 2002). In the perforation process, the worm dissolves the shell using secretions together with the action of falcate notochaetae spines (modified chaetae) from chaetiger fifth to form a shaped-U hollow that has a central island filled by thin detritus, which can have almost $20 \mathrm{~mm}$ of length (Zottoli \& Carriker, 1974).

The presence of drilling organisms in mollusks shells cause damage to these hosts, weakening the limestone skeleton, increasing the energy expenditure for shell maintenance and may be vectors of diseases, factors that reduce its commercial value, and condition reduced index (Wargo \& Ford, 1993; Handley \& Bergquist, 1997; Boscolo \& Giovanardi, 2002; Read, 2010). The infestation degree of polydorids varies between oyster species and suffers a direct influence of environmental parameters, mainly the temperature (Nel et al., 1996; Handley \& Bergquist, 1997). Large infestations can leave the host vulnerable and hence more susceptible to predators such as crabs. Often the infestations are not visible in the new polydiariosis (Boscolo \& Giovanardi, 2002; Sabry \& Magalhães, 2005).

The relationships between oysters and infesting polychaetes remain unknown for several localities (Blake \& Kudenov, 1978; Radashevski, 2013). Radashevski et al. (2006) studied Polydora species of South America, but do not consider the presence of Polydora websteri Hartman in Loosanoff \& Engle, 1943. These authors 
identified $P$. rickettsi Wooddwick, 1962, $P$. ecuadoriana Blake, 1983, P. haswelli Blake \& Kudenov, 1978 and described a new species $P$. carinhosa. However, $P$. websteri was synonymized in that paper by $P$. cf. haswelli.

Crassostrea cf. brasiliana occurs from Maranhão to Santa Catarina, in mangroves and rocky shores (Amaral \& Simone, 2014). This study aims to determine the diversity of polydorids polychaetes within $C$. cf. brasiliana and their infestation and prevalence rates from five estuaries of Northeastern Brazil.

\section{Material and Methods}

Samplings were collected in five estuaries from the coast of Pernambuco: Goiana River (GR) and Santa Cruz Canal (SC), Capibaribe River (CR); Massangana River (MR) and Sirinhaém River (SR) (Figure 1). The specimens were carried out in each River at three sites 50 meters distant from each other in the estuary with the highest oyster's density. Twenty oysters were collected at each location, being ten in subtidal and ten at intertidal. The material was fixed in formaldehyde $4 \%$ solution buffered with salt water and later rinsed with fresh water. Posteriorly the material was transferred to alcohol $70 \%$.

The height and width of valves were measured, and the epifaunal organisms were removed. The drilling organisms were counted and removed. The shells were broken with cutting pliers to remove the infaunal organisms. All the individuals were wrapped and labeled separately in pots of $10 \mathrm{ml}$ with $70 \%$ alcohol.

The infestation rate was calculated by the number of organisms per oyster, and the prevalence rate as the percentage of infested oysters in a given site. The differences between the infestation rates in the studied estuaries were heteroscedastic, and thus analyzed by the KruskalWallis, with Dunn test a posteriori. However, to analyze the infestation rate in the Capibaribe River, the ANOVA was used because the variance was homogeneous. The differences between the richness of species were verified from the Kruskal-Wallis-Dunn.

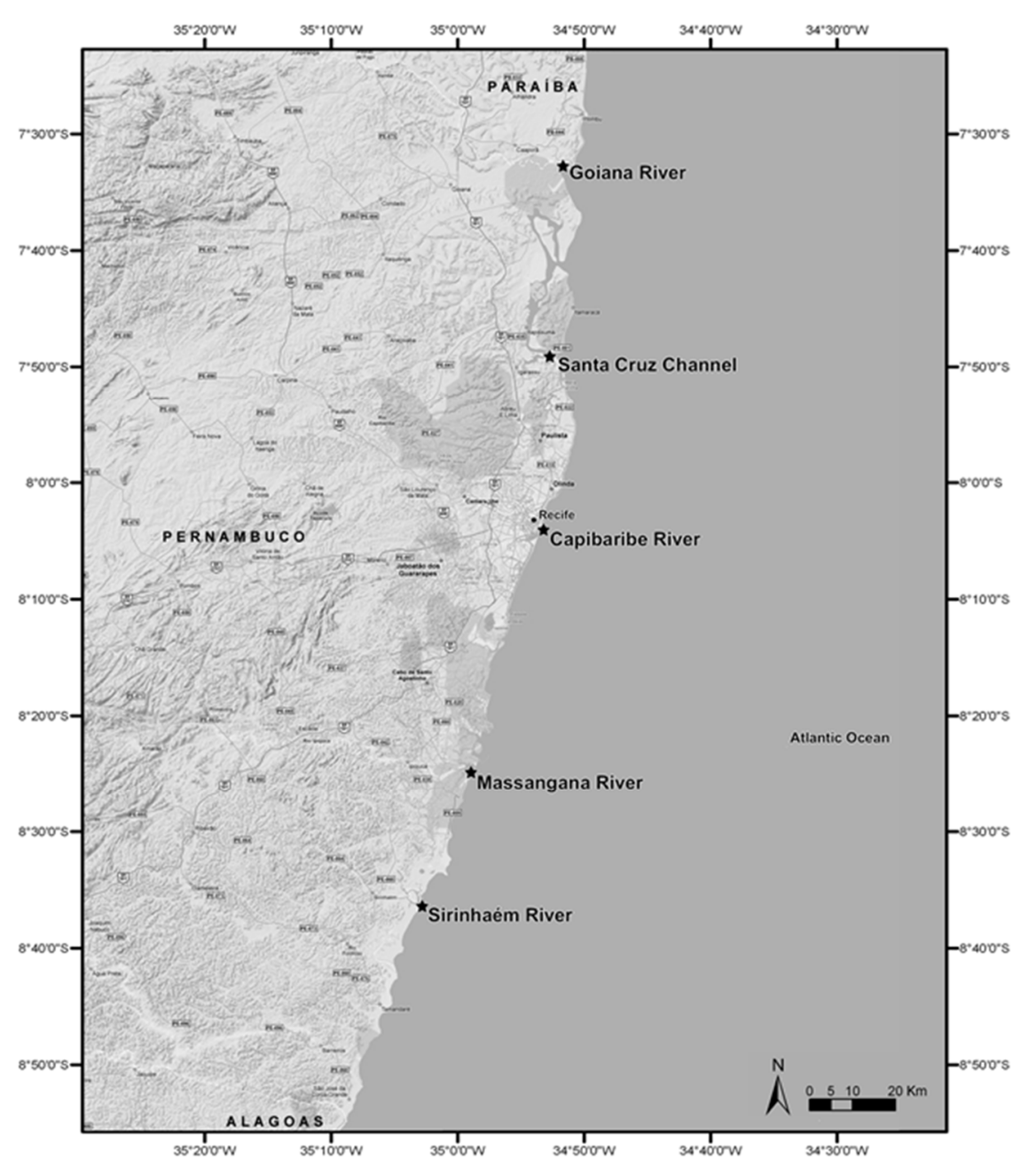

Figure 1. Map of the study area showing the five studied estuaries in Pernambuco State, Brazil. 


\section{Results}

The organisms inside shell holes were found in $47 \%$ of observed oysters, with five species and almost three thousand specimens: $P$. websteri, with $98 \%$ of the total number of organisms, and Boccardiella ligerica (Ferronière, 1898) were considered as true drillers. The other organisms found in the holes were the tanaidacean Sinelobus stanfordi (Richardson, 1901), the sabellid Chone sp. and the syllid Syllis sp.

The occurrence of these five species and prevalence rates were different among estuaries, with no recorded species in Massangana River. $B$. ligerica, however, occurred only in Goiana and Sirinhaém.

The infestation rate of $P$. websteri within intertidal oysters was significantly higher in the Capibaribe estuary (Figure 2) when compared to the other three estuaries (Kruskal-Wallis/Dunn, $\left.\mathrm{H}_{(3,136)}=56.84, \mathrm{p}<0.0001\right)$. In this estuary, the oyster at the sublittoral showed a significantly higher infestation rate than on the intertidal region $\left(\mathrm{F}_{(1,58)}=4.69, \mathrm{p}=0.0344\right)$, with an average of 61.1 individuals per oyster in the sublittoral against 28.3 individuals per the oyster in the intertidal region.

The $P$. websteri prevalence rate in oysters at Capibaribe River reached almost $100 \%$ in sublittoral and about $70 \%$ of the intertidal region. In other estuaries in the prevalence, rates were lower and did not reach $40 \%$ of an infestation. A significant relationship between the oyster size and parasitism rate $(r=0.43)$ was found only in the Capibaribe River, with $18 \%$ of the variation in the number of parasites explained by the size of shells.

The oysters from the Capibaribe River were most affected by the presence of the spionid $P$. websteri, whereas the oysters from the Sirinhaém River were hardest hit damaged by the spionid B. ligerica. The morphological pattern of bubbles caused by both infestations was similar.

Boccardiella ligerica was found only in Goiana and Sirinhaém Rivers, despite the low number of individuals found (24), the prevalence of $B$. ligerica was important in the Sirinhaém River, with $25 \%$ of oysters colonized, and an infestation rate of $0.5 \mathrm{~B}$. ligerica per oyster sampled. In Goiana River only a single oyster showed the presence of $B$. ligerica.

The oysters differed in size since those from Capibaribe were significantly larger than specimens collected in Massangana, Sirinhaém, and Santa Cruz estuaries (KruskalWallis/dunn, $\mathrm{n}=165 ; \mathrm{p}<0.05$ ) (Figure 3).
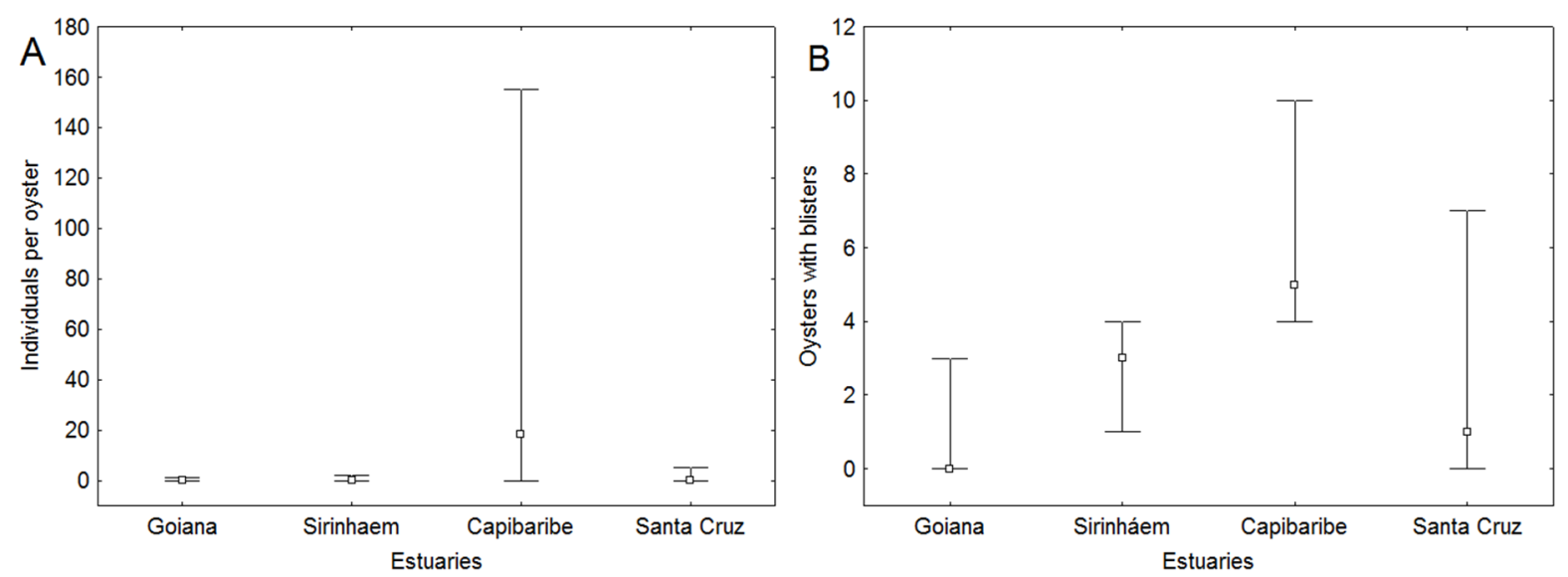

Figure 2. Median (non-outlier range) Infestation rate (A) and prevalence (B) by Polydora websteri in Crassotraea cf brasiliana on five estuaries from Northeast Brazil.

The epifaunal polychaetes were found in 80 of 165 oysters sampled. They were represented by 13 species, with a mean richness of 1.6 species per oyster; however, no significant differences were observed in richness and dominance among the studied estuaries. There was a significant linear regression between the length of the shell and the polychaetes number (Table 1). The regression's slope of Capibaribe and Sirinhaém were significantly different from the other estuaries; conversely, Goiana's slope was not significantly different from Santa Cruz. The species $P$. websteri accounted for $48 \%$ of the total number of polychaetes and the serpulid $F$. uschakovi, 36\%; and B. ligerica was the third most abundant organism with $10 \%$. In Massangana Estuary only one specimen had epifaunal organisms. There were no differences in structure among the other four estuaries, but, as shown by the MDS plot, differences in species composition occurred (Figure 4). 


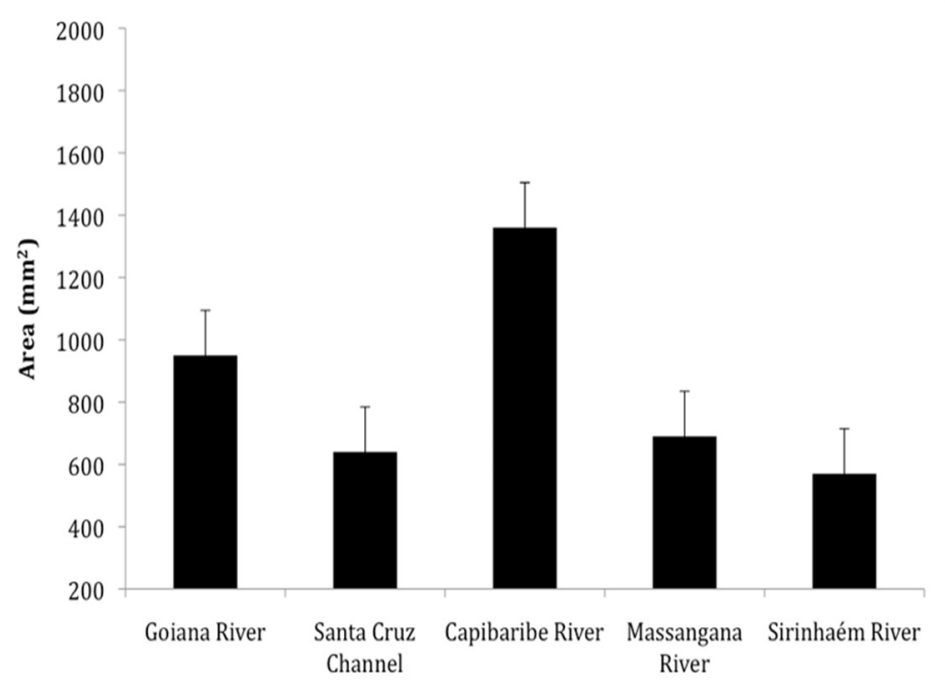

Figure 3. Average ( \pm S.E.) areas of the shell (length $\mathrm{x}$ width) of oysters (Crassostrea cf. brasiliana ) per estuary.

Table 1. Linear regression between shell length of Crassostrea cf. brasiliana and number of epifaunal polychaetes at five estuaries of Pernambuco State coast; $r^{2}=$ Determination coefficient, $n=$ numbers of oyster with polychaetes. Estuaries: $\mathrm{GO}=$ Goiana, $\mathrm{SC}=$ Santa Cruz, $\mathrm{CP}=$ Capibaribe, $\mathrm{MS}=$ Massangana, $\mathrm{SR}$ $=$ Sirinhaém.

\begin{tabular}{lccccc}
\hline & GO & SC & CP & MS & SR \\
\hline Intercept & 33.52 & 30.61 & 5.32 & - & 24.86 \\
slope & 0.91 & 0.86 & 1.78 & - & 1.23 \\
$\left(\mathrm{r}^{2}\right)$ & 0.75 & 0.72 & 0.69 & - & 0.20 \\
\hline $\mathbf{n}$ & $\mathbf{5}$ & $\mathbf{9}$ & $\mathbf{3 6}$ & $\mathbf{1}$ & $\mathbf{2 9}$ \\
\hline
\end{tabular}

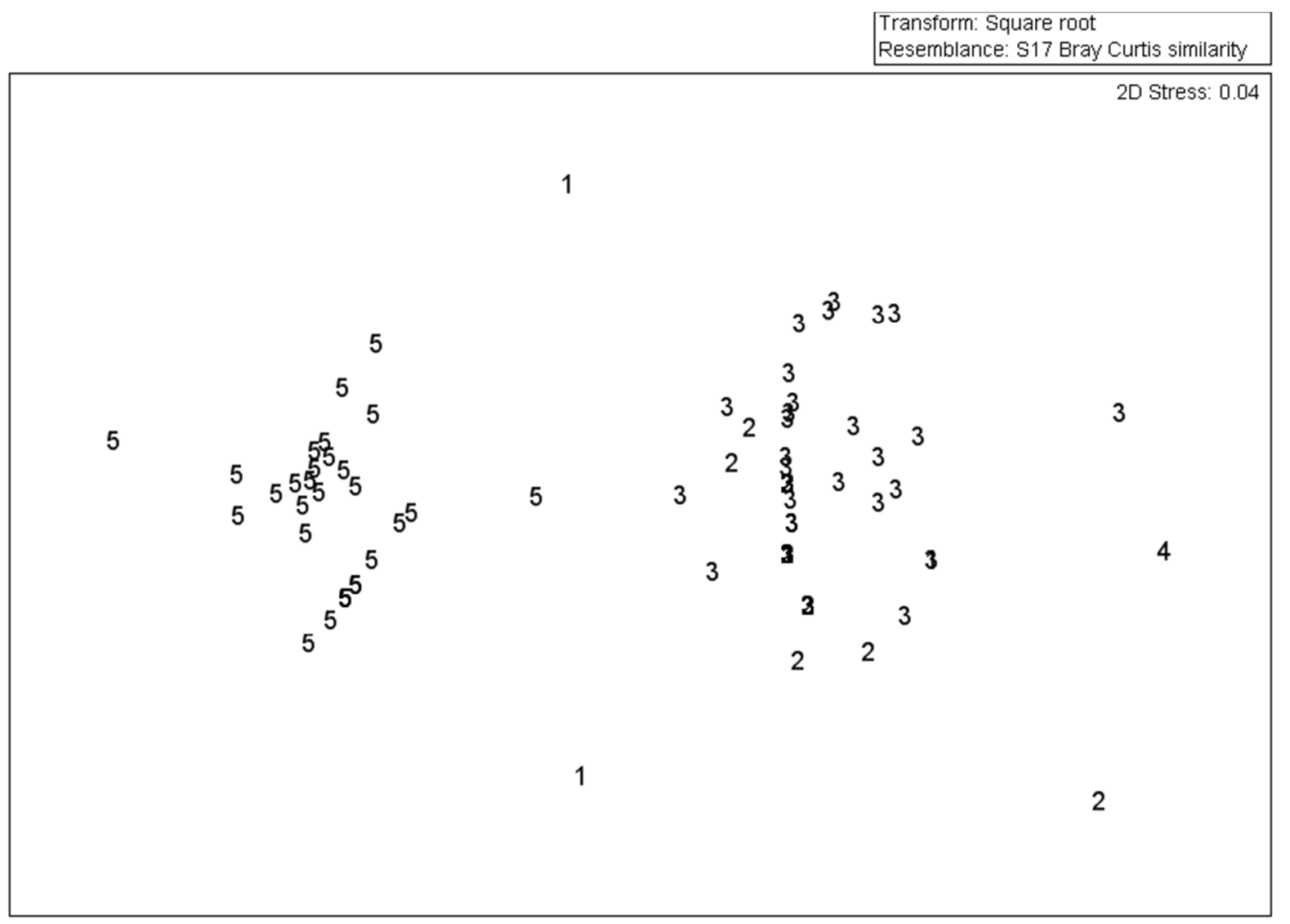

Figure 4. Multidimensional scaling plot of oysters Crassostrea cf. brasiliana based on polychaete species composition and density. 1 - Goiana estuary, 2 - Santa Cruz, 3 - Capibaribe, 4 - Massangana, 5 - Sirinhaém. 


\section{Discussion}

The shell blisters infestation in $C$. cf. brasiliana were different among the estuaries of Pernambuco, and between inter and subtidal areas either. The oysters collected in Capibaribe River showed high infestation and prevalence levels, with shells completely occupied by tubes of $P$. websteri and almost $100 \%$ of sublittoral oysters infested. High infestation rates are usually observed in other places (Ghode \& Kripa, 2001; Díaz \& Liñero-Arana, 2009). Ghode \& Kripa (2001) found oysters (Crassostrea madrasensis) infested by the blister worm Polydora ciliata in the Ashtamudi Lake, India; the infestation rate was higher in farmed than in the natural beds, where more than $50 \%$ of oysters older than 24 months presented severe infestation rate. Diaz \& Liñero-Arana (2009) analyzed 175 oysters $(C$. rhizophorae) and found only 10 oysters with severe infestation and 42 with a median infestation.

The prevalence rates larger than $50 \%$ of oysters were found in other studies (Wargo \& Ford, 1993; Handley, 1995; Handley \& Bergquist, 1997; Ghode \& Kripa, 2001; Sabry \& Magalhães, 2005; Días \& Liñero-Arana, 2009). The mudblisters were present in $68.3 \%$ of the wild oysters $C$. gigas collected from the three study sites and $90 \%$ of the commercial oysters (Handley \& Bergquist, 1997). The prevalence is increased with age, where $20 \%$ of small oysters $(<6$ months) were infested and all farmed oysters above two years had Polydora infestation (Ghode \& Kripa, 2001). In South Brazil, the infestation by polydorids may vary with host and time: $C$. gigas and $C$. rhizophorae presented a high prevalence by $P$. websteri. All $C$. gigas individuals were infected with polydiariosis parasites (100\%) throughout the experimental period; whereas $100 \%$ prevalence of $C$. rhizophorae with polydiariosis was observed only in February and May on oyster cultures (Sabry \& Magalhães, 2005).

Diaz \& Liñero-Arana (2009) found an infestation prevalence of $64.6 \%$ in oysters from La Laguna Costera La Restinga, al Norte de la Isla de Margarita, Venezuela. This lagoon presented high concentrations of organic matter (Salazar et al., 2003), similar as found in the eutrophic estuary Capibaribe River (Feitosa et al., 1999), with the highest prevalence rates of polydorids. In Capibaribe's estuary, the infestation rate and prevalence of $P$. websteri were strongly correlated with intertidal exposure levels; the incidence of $P$. websteri infestations was higher in intertidal, in agreement with other field studies (Handley \& Bergquist, 1997; Royer et al., 2006).
In this study, the number of polydorids (blisters) per oysters followed a linear relationship with high infestation rates, and although the relationship is significant, it is statistically very weak. Several factors have been cited to explain the infestation rate in oysters, as shown by Lauckner (1983). The author states that salinity, temperature, and type of substrate are key components to the abundance of $P$. websteri and that prevalence of up to $100 \%$ is not uncommon. Martin \& Britayev (1998) showed that polydorids rarely reach infestation rates as high as 1,500 worms to a shell; in general, there are a few dozen worms per shell, as demonstrated by Sabry \& Magalhães (2005) and in the present study.

The presence of epifaunal polychaetes in Pernambuco's estuaries varied significantly among them. The occurrence is increased with the size of the oyster. The higher level of colonization detected in larger bivalves by epifaunal polychaetes was registered in Haliotis rufescens in Southern Chile (Vargas et al., 2005). Royer et al. (2006) and Taylor et al. (1997) identified a diverse epibiota associated to Crassostrea gigas and Pinctada maximum, composed by barnacles (Elminius modestus, Balanus crenatus and Balanus perforatus), serpulid polychaetes (Pomatoceros sp.) spirorbids (Spirorbis sp.) mytillides mollusks (Mytilus edulis) and ascidians. Royer et al. (2006) observed that the greater diversity of epibiont organisms occurred in the lower points of the estuary, attributing the highest species richness at the time of immersion. These authors also found that polydorids occur in low numbers in the small-size oysters' $C$. gigas and the number rapidly increased in the intermediate and market sizes. Lesser et al. (1992) and Taylor et al. (1997) argue that epibiont organisms compete for food with the bivalve host and thus decrease the biomass of the phytoplankton available. Oyster's growths are significantly reduced if its fouling organisms are not removed regularly, as observed for Pinctada maxima (Taylor et al., 1997). Crassostrea rhizophorae supports fouling organisms up to $47 \%$ of its upper valve weight without affecting the growth of the valve and tissue; however if the fouling mass weight is greater than 3 fold the upper valve weight and if is located in the and ventral edge of it, mortality will increase (Lodeiros et al., 2007). Thus, it is possible to observe the importance of epibionthic wildlife on growth and survival of oysters (Lodeiros \& Himmelman, 2000).

\section{Acknowledgements}

The authors thank Catarina Silva for the identification of the tanaidaceans and the Glória 
Freitas for the taxonomical identification of mollusks species. Authors acknowledge to CNPq and FACEPE for a postdoctoral scholarship to De Assis JE.

\section{References}

AMARAL, V. S.; SIMONE, L. R. L. 2014. Revision of genus Crassostrea (Bivalvia: Ostreidae) of Brazil. J. Mar. Biol. Assoc. UK., v.94, n.4, p. 811-836.

BLAKE, J. A. 1996. Family Spionidae Grube 1850. Including a review of the genera and species from California and a revision of the Genus Polydora Bosc, 1802. In: BLAKE, J. A.; HILBIG, B.; SCOTT, P. H. (Eds.). Taxonomic atlas of the benthic fauna of the Santa Maria Basin and Western Santa Bárbara Channel. The Annelida part 3. Califórnia: Santa Bárbara Museum of Natural History, pp.81-243.

BLAKE, J. A.; KUDENOV, J. D. 1978. The Spionidae (Polychaeta) from southeastern Australia and adjacent areas with revision of the genera. Mem. Nat. Mus. Vict., v.39, p.171-280.

BOSCOLO, R.; GIOVANARDI, O. 2002. Polydora ciliata shell infestation in Tapes philippinarum Manila clam held out of the substrate in the Adriatic Sea, Italy. J. Invertebr. Pathol., v.79, p.197-198.

BOWER, S. M.; MCGLADDERY, S. E.; PRICE, I. M. 1994. Synopsis of infectious diseases and parasites of commercially exploited shellfish. Annu. Rev. Fish Dis., v.4, p.1-199.

DÍAS, O.; LIÑERO-ARANA, I. 2009. Percentage of infestation level of Polydora cf. websteri Hartman, 1943 (Polychaeta: Spionidae) by size class of Crassostrea rhizhophorae (Guilding, 1828). Rev. Científica, v.19, n.2, p.113-118.

FEITOSA, F. A. N.; NASCIMENTO, F. C. R.; MUNIZ, K. 1999. Distribuição espacial e temporal da biomassa fitoplanctônica relacionada com parâmetros hidrológicos na Bacia do Pina (Recife-PE). Trab. Oceanogr. Univ. Fed. PE, v.27, p.1-13.

GHODE, G. S.; KRIPA, V. 2001. Polydora infestation on Crassostrea madrasensis : a study on the infestation rate and eradication methods. J. Mar. Biol. Assoc. India, v.43, n.1-2, p. 110-119.

HANDLEY, S. J. 1995. Spionid polychaetes in Pacific oysters, Crassostrea gigas (Thunberg) from Admiralty Bay, Marlborough Sounds, New Zealand. New Zeal J Mar. Fresh, v.29, p.305-309.

HANDLEY, S. J.; BERGQUIST, P. R. 1997. Spionid polychaete infestations of intertidal pacific oysters Crassostrea gigas (Thunberg), Mahurangi Harbour, Northern New Zealand. Aquaculture, v.153, p.191-205.

LESSER, M. P.; SHUMWAY, S. E.; CUCCI, T.; SMITH, J. 1992. Impact of fouling organisms on mussel rope culture: interspecific competition for food among suspension-feeding invertebrate. J Exp. Mar. Biol. Ecol., v.165, p.91-102.

LODEIROS, C. J. M.; HIMMELMAN, J. H. 2000. Identification of factors affecting growth and survival of the tropical scallop Euvola (Pecten) ziczac in the golfo de Cariaco, Venezuela. Aquaculture, v.182, p. 91-114.

LODEIROS, C. J. M.; GALINDO, L.; BUITRAGO, E.; HIMMELMAN, J. H. 2007. Effects of mass and position of artificial fouling added to the upper valve of the mangrove oyster Crassostrea cf. brasiliana on its growth and survival. Aquaculture, v.262, p.168-171.

MARTIN, D.; BRITAYEV, T. A. 1998. Symbiotic polychaetes: review of known species. Oceanogr. Mar. Biol., v.36, p.217-340.

NEL, R.; COETZEE, P. S.; NIEKERK, G. V. 1996. The evaluation of two treatments to reduce mud worm (Polydora hoplura Claparède) infestation in commercially reared oysters (Crassostrea gigas Thunberg). Aquaculture, v.141, p.31-39.

RADASHEVSKY, V. I. 2012. Spionidae (Annelida) from shallow waters around the British Islands: an identification guide for the NMBAQC Scheme with an overview of spionid morphology and biology. Zootaxa, v.3152, p.1-35

READ, G. B. 2010. Comparison and history of Polydora websteri and P. haswelli (Polychaeta: Spionidae) as mud-blister worms in New Zealand shellfisch. New zeal. J. Mar. Fresh., v.44, n.2, p. $83-100$.

ROYER, J.; ROPERT, M.; MATHIEU, M.; COSTIL, K. 2006. Presence of spionid worms and other epibionts in Pacific oysters (Crassostrea gigas) cultured in Normandy, France. Aquaculture, v.253, p.461-474. 
SABRY, R. C.; MAGALHÃES, A. R. M. 2005. Parasitas em ostras de cultivo (Crassostrea rhizophorae e Crassostrea gigas) da Ponta do Sambaqui, Florianópolis, SC. Arq. Bras. Med. Vet. Zootec., v.57, n.2, p.194-203.

SALAZAR, J. C.; ROSAS, J. A.; RODRÍGUEZ, J. C. 2003. Condiciones sedimentológicas de la laguna la restinga, isla de margarita, Venezuela. Interciencia, v.28, n.1, p.44-50.

SATO-OKOSHI W. 2000. Polydorid species (Polychaeta: Spionidae) in Japan, with descriptions of morphology, ecology and burrow structure. 2. Non-boring species. J. Mar. Biol. Assoc. UK, v.80, p.443-456.

TAYLOR, J. J.; SOUTHGATE, P. C.; ROSE, R. A. 1997. Fouling animals and their effect on the growth of silver-lip pearl oysters, Pinctada maxima (Jameson) in suspended culture. Aqualculture, v.153, p.31-40.
VARGAS, L.; QUIJON, P.; BERTRAN, C. 2005. Polychaete infestation in cultured abalone (Haliotis rufescens Swainson) in Southern Chile. Aquac. Res., v.36, p.721-724.

WARGO, R. N.; FORD, S. E. 1993. The Effect of shell infestation by Polydora sp. and infection by Haplosporidium nelsoni (MSX) in the tissue condition of oysters, Crassostrea virginica. Estuaries, v.16, p.229-234.

WILLIAMS, J. D. 2000. A new species of Polydora (Polychaeta: Spionidae) from the IndoWest Pacific and first record of host hermit crab egg predation by a commensal polydorid worm. Zool. J. Linn. Soc-Lond., v.129, p.537-548

ZOTTOLI, R. A.; Carriker, M. R. 1974. Burrow morphology, tube formation, and microarchitecture of shell dissolution by the spionid polychaete Polydora websteri. Mar. Biol., v.27, n.4, p.307-316. 